\title{
Amino acid concentrations in seed of preferred forages of bobwhites
}

\author{
JON C. BOREN, ROBERT L. LOCHMILLER, DAVID M. LESLIE, JR., AND DAVID M. \\ ENGLE
}

Authors are research assistant, Department of Agronomy; associate professor, Department of Zoology; Unit Leader, U.S. Fish and Wildlife Service, Oklahoma Cooperative Fish and Wildlife Research Unit; and professor, Department of Agronomy, Oklahoma State University, Stillwater 74048.

\begin{abstract}
Nutritional factors have been hypothesized to regulate gallinaceous bird populations such as the Northern Bobwhite (Colinus virginianus). Although protein is considered one of the most important and limiting nutrient categories in wild animal populations, we lack a complete understanding of the availability of essential amino acids in foodstuff protein. Seed grains comprise a major component of the annual diet of bobwhites throughout its geographic range. We investigated the concentration of 17 amino acids in seed of 4 highly preferred forages of bobwhites from central Oklahoma. The total nitrogen content of seed was composed of $28-43 \%$ nonamino nitrogen of limited nutritional value. We provide evidence that crude protein may grossly over estimate true protein. Amino acid content of forages in lieu of crude protein may better describe the nutritional ecology of quail and other gallinaceous birds and provide new insights into the role of nutrition in regulating animal populations.
\end{abstract}

Key Words: Colinus virginianus, crude protein, nonamino nitrogen, nutrition

Seed grains comprise a major component of the annual diet of bobwhite quail throughout its geographic range (Bookhout 1958, Robel and Slade 1965). Bobwhites show a distinct preference for seeds of wooly croton (Croton capitatus Michx.), common sunflower (Helianthus annuus L.), Florida paspalum (Paspalum floridanum Michx.), and western ragweed (Ambrosia psilostachya DC.) in rangelands of central Oklahoma (Baumgartner et al. 1952, Wiseman 1977, Rollins 1980, Tobler and Lewis 1981). Management practices have been developed to increase forage availability and diet quality for Northern Bobwhites (Colinus virginianus) (Wiseman and Lewis 1981, Webb and Guthery 1982). Although considerable efforts have been devoted to documenting crude protein in foods (Nestler et

This is journal article J-6241 of the Oklahoma Agricultural Experiment Station. This study was funded in part by the National Science Foundation (BSR-8657043), Oklahoma Agricultural Experiment Station, Kerr Foundation, Oklahoma Cooperative Fish and Wildlife Research Unit (Fish and Wildlife Service, Oklahoma Department of Wildlife Conservation, Oklahoma State University, and Wildlife Management Institute, cooperating), and the Department of Zoology, Oklahoma State University.

Manuscript accepted 19 Aug.1994 al. 1945, Newlon et al. 1964) and diets (Wood et al. 1986) of Northern Bobwhites, no attempts to document true protein concentration of food proteins and diets of bobwhites or other gallinaceous birds exist to our knowledge.

White (1978) proposed that available nitrogenous nutrients were the most limiting environmental resource to wild herbivore populations. Scarce quantities of digestible protein in plant material, high nitrogen requirements for reproduction, differential forage selectivity by individuals, and high juvenile mortality rates were offered as strong supporting evidence by White (1978). Because proteins vary considerably in amino acid composition, they also vary greatly in their nutritive quality. As a result, crude protein contents of diets may provide a poor index of protein quality (Sedinger 1984). Sedinger's (1984) analysis of amino acid concentrations in a variety of tundra plants used by geese indicated that crude protein determinations can overestimate true protein content by $22-52 \%$. Many agricultural cereal grains and legumes also are poor sources of amino acids despite a high concentration of crude protein (Deyoe and Shellenberger 1965, Hang et al. 1980). We hypothesize that similar discrepancies exist with foods utilized by bobwhites, especially, given the high concentrations of nonamino nitrogen constituents found in many cultivated and weed seed grains (VanEtten et al. 1967, Holt and Sosulski 1981).

Although protein is thought to be one of the most important and limiting nutrients in wild populations, we unfortunately lack a complete understanding of its essential components, namely the amounts of essential amino acids. We choose to examine the quality of protein in seed from 4 ubiquitous plant species that are highly preferred and consumed in large amounts by bobwhites (Wood et al. 1986). Our primary objective was to document the amino acid composition in seed collected from central Oklahoma. We hypothesize that crude protein determinations may greatly overestimate true protein content of seed utilized by bobwhites.

\section{Methods}

We examined seed of wooly croton, common sunflower, Florida paspalum, and western ragweed for variation in the quality of protein by profiling concentrations of their respective amino acids on the Cross Timbers Experimental Range, Payne County, Oklahoma $\left(36^{\circ} 2^{\prime}\right.$ to $36^{\circ} 4^{\prime} \mathrm{N}, 97^{\circ} 9^{\prime}$ to $\left.97^{\circ} 11^{\prime} \mathrm{W}\right)$ located in the cross timbers land resource area (Garrison et al. 1977). 
Vegetation on the study area is similar to that of other areas in the cross timbers and is dominated by post oak (Quercus stellata Wang.) and black-jack oak (Quercus marilandica Muenchh.) in the overstory with interspersed tallgrass prairie (Ewing et al. 1984). Detailed descriptions of the study area have been previously published (Engle et al. 1991, Lochmiller et al. 1991, Stritzke et al. 1991).

All mature seeds of each species were harvested from approximately 100 plants on each of 4 different 32-ha sample plots from 13 September to 25 October 1990 . Seeds of each species were pooled $(n=1)$ within each sample plot before laboratory analysis.

Seeds were separated from other plant material, cleaned by sieving, and composited by species and habitat type before further processing. Approximately 5-g subsamples were dried by lyophilization and ground to a fine powder using a micro-grinding mill. Fat content was assessed by ether-extraction using a Soxhlet apparatus (AOAC 1984). Total nitrogen was determined by micro-Kjeldahl analysis and converted to crude protein by multiplying the percent nitrogen by 6.25 (AOAC 1984).

Fat-extracted seed samples amounting to approximately $40 \mathrm{mg}$ of protein were weighed into $25 \times 150 \mathrm{~mm}$ glass tubes with teflon caps and hydrolyzed in $15 \mathrm{ml} 6 \mathrm{~N} \mathrm{HCl}$ under a nitrogen blanket at $110^{\circ} \mathrm{C}$ for 24 hours. One $\mathrm{ml}$ of the hydrolyzed sample was filtered through a $0.45-\mu \mathrm{m}$ syringe filter ${ }^{1}$. Amino acids in the hydrolysates were precolumn derivatized with phenylisothiocynate and separated on a PICO:TAG reverse-phase column ${ }^{2}$ (Cohen 1988). Derivatized amino acids were detected on-line spectrophotometrically and measured by comparing the area under the sample peak against that of an amino acid standard solution (Pierce $\mathrm{H}$ standard, Sigma Chemical) of known concentration. Concentrations of 17 individual amino acids were determined using high pressure liquid chromatography (HPLC). Tryptophan, an essential amino acid comprising about $<1.0 \%$ of the total dry mass of seeds (Harrold and Nalewaja 1977), was destroyed by acid hydrolysis and therefore not measured. A casein reference protein ${ }^{3}$ of known amino acid composition was hydrolyzed and analyzed along with seed samples. Sulfur-containing amino acid loss during acid hydrolysis (Spindler et al. 1984, Elkin and Griffith 1985) averaged $15 \%$ for methionine and $35 \%$ for cystine. Therefore methionine and cystine concentrations recovered were adjusted upward by 15 and $35 \%$ respectively. Amino acid concentrations were recorded as a relative proportion of the total amino acid content and on a dry mass basis.

Nonamino nitrogen concentrations in seed were a measure of the difference between amino acid nitrogen (HPLC analysis) and the total nitrogen (Kjeldahl analysis) contents. Nonamino nitrogen was assumed to be all nitrogen not incorporated into one of the amino acids recovered (HPLC analysis) and was assumed to be made up of a diverse group of compounds (Bell 1963, Synge 1963, Maynard et al. 1979). Unlike other measures of non-protein nitrogen (Holt and Sosulski 1981), we did not include free amino acids (those amino acids not bound to protein) that were recovered during HPLC analysis. Crude protein estimates were corrected (true protein + free amino acids) for nonamino nitrogen concentrations.

Differences in percent fat, crude protein, nonamino nitrogen, and amino acid concentration among plant species were tested by

Acrodisc CRPTF, Flsher Scientific, Plano, Tex.

'Waters, Milford, Mass.

'Bovine milk, no. C-0376, Sigma Chem. Co., St. Louis Mo. analysis of variance (PROC ANOVA, SAS 1988). We used the least significant differences test to isolate significant differences among means in the presence of a significant $F$-test $(P<0.05)$.

\section{Results}

Variation in concentration of individual amino acids within a plant species was greater when expressed on a percent dry mass basis than relative percent of the total amino acid pool due to variation in percent crude protein (see SE in Tables 1 and 2). Crude protein differed $(P<0.01)$ among all plant species and ranged from $5.1 \%$ for Florida paspalum to $16.3 \%$ for wooly croton (Table 1). Differences were also noted for concentration of fat among plant species $(P<0.01)$; fat was lower in Florida paspalum than in other species and lower in western ragweed than in common sunflower.

Methionine and cystine were the least concentrated amino acids among seed species. Amino acid concentrations (\% dry mass basis) ranged from 1.823 for glutamic acid to 0.011 for cystine. Amino acids were classified as essential or nonessential according to the NRC (1984) requirements. All essential and nonessential amino acids differed $(P<0.05)$ among plant species when expressed as a relative percent of the total amino acid content (Table 1). This indicated that the quality of proteins as measured by the essential amino acid composition varied considerably among species. Differences in amino acids among plant species when expressed on a dry mass basis were less apparent (Table 2).

Whether the observed levels of the essential amino acids are adequate in meeting aduit maintenance requirements can not be adequately determined because requirements for the nutrients have not been specifically determined for bobwhite quail. However, requirement information has been provided for a relat-

Table 1. Mean ( $n=5)$ percent fat, crude protein, and amino acid composition of wooly croton, Florida paspalum, western ragweed, common sunflower, and casein. Amino acids expressed as a percent of total amino acid.

\begin{tabular}{lcccccc}
\hline \hline Amino Acid & Croton & Paspalum & Ragweed & Sunflower & SE & Casein $^{\mathrm{l}}$ \\
\hline Fat \% & $18.08^{\mathrm{ab}}$ & $0.60^{\mathrm{c}}$ & $14.73^{\mathrm{b}}$ & $20.14^{\mathrm{a}}$ & 1.88 & \\
Crude Protein \% & $16.27^{\mathrm{a}}$ & $5.07^{\mathrm{d}}$ & $9.17^{\mathrm{c}}$ & $13.83^{\mathrm{b}}$ & 0.02 & 83.00 \\
Essential Amino Acids & & & & & & \\
Arginine & $9.47^{\mathrm{a}}$ & $3.66^{\mathrm{c}}$ & $6.72^{\mathrm{b}}$ & $6.28^{\mathrm{b}}$ & 0.31 & 3.94 \\
Histidine & $2.57^{\mathrm{a}}$ & $1.60^{\mathrm{c}}$ & $2.05^{\mathrm{b}}$ & $1.88^{\mathrm{b}}$ & 0.02 & 2.43 \\
Isoleucine & $4.93^{\mathrm{a}}$ & $4.30^{\mathrm{b}}$ & $4.78^{\mathrm{a}}$ & $4.92^{\mathrm{a}}$ & 0.02 & 4.82 \\
Leucine & $6.32^{\mathrm{c}}$ & $8.94^{\mathrm{a}}$ & $7.06^{\mathrm{b}}$ & $6.79^{\mathrm{b}}$ & 0.07 & 9.64 \\
Lysine & $4.69^{\mathrm{a}}$ & $3.53^{\mathrm{b}}$ & $4.31^{\mathrm{ab}}$ & $4.56^{\mathrm{a}}$ & 0.34 & 9.07 \\
Methionine & $1.32^{\mathrm{a}}$ & $0.71^{\mathrm{b}}$ & $0.53^{\mathrm{b}}$ & $0.84^{\mathrm{b}}$ & 0.04 & 2.69 \\
Phenylalanine & $4.08^{\mathrm{b}}$ & $5.32^{\mathrm{a}}$ & $3.85^{\mathrm{b}}$ & $3.88^{\mathrm{b}}$ & 0.14 & 4.32 \\
Threonine & $3.73^{\mathrm{b}}$ & $4.26^{\mathrm{a}}$ & $4.06^{\mathrm{a}}$ & $3.68^{\mathrm{b}}$ & 0.05 & 4.03 \\
Valine & $7.28^{\mathrm{a}}$ & $6.40^{\mathrm{b}}$ & $5.93^{\mathrm{c}}$ & $6.55^{\mathrm{b}}$ & 0.08 & 6.15 \\
& & & & & & \\
Nonessential Amino Acids & & & & & \\
Alanine & $6.91^{\mathrm{b}}$ & $12.98^{\mathrm{a}}$ & $6.79^{\mathrm{b}}$ & $6.75^{\mathrm{b}}$ & 0.21 & 3.27 \\
Aspartic acid & $11.10^{\mathrm{a}}$ & $8.86^{\mathrm{b}}$ & $10.83^{\mathrm{a}}$ & $10.08^{\mathrm{ab}}$ & 0.68 & 9.08 \\
Cystine & $0.34 \mathrm{a}$ & $0.13 \mathrm{~b}$ & $0.33 \mathrm{a}$ & $0.15 \mathrm{~b}$ & 0.01 & 0.00 \\
Glutamic acid & $14.70^{\mathrm{b}}$ & $15.72^{\mathrm{b}}$ & $19.28^{\mathrm{a}}$ & $18.88^{\mathrm{a}}$ & 1.33 & 19.29 \\
Glycine & $10.61^{\mathrm{ab}}$ & $7.09^{\mathrm{c}}$ & $9.48^{\mathrm{b}}$ & $11.87^{\mathrm{a}}$ & 0.88 & 2.37 \\
Proline & $5.61^{\mathrm{c}}$ & $8.20^{\mathrm{a}}$ & $6.48^{\mathrm{b}}$ & $6.29^{\mathrm{b}}$ & 0.11 & 9.08 \\
Serine & $3.94 \mathrm{~b}$ & $5.83 \mathrm{a}$ & $6.00 \mathrm{a}$ & $4.48 \mathrm{~b}$ & 0.46 & 5.09 \\
Tyrosine & $2.46 \mathrm{a}$ & $2.47 \mathrm{ab}$ & $1.52 \mathrm{c}$ & $2.12 \mathrm{~b}$ & 0.05 & 4.74 \\
Total & 100.06 & 100.00 & 100.00 & 100.00 & & 100.01 \\
\hline
\end{tabular}

'Reference protein $(n=1)$

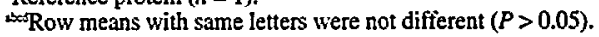


Table 2. Mean $(n=5)$ amino acid composition of wooly croton, Florida paspalum, western ragweed, common sunflower, and casein. Amino acids expressed as a percent of dry mass basis.

\begin{tabular}{lllllll}
\hline \hline Amino Acid & Croton & Paspalum & Ragweed & Sunflower & SE & Casein $^{\mathrm{l}}$ \\
\hline Essential Amino Acids & & & & & \\
Arginine & $1.285^{\mathrm{a}}$ & $0.223^{\mathrm{b}}$ & $0.690^{\mathrm{b}}$ & $0.717^{\mathrm{b}}$ & 0.278 & 0.374 \\
Histidine & $0.306^{\mathrm{a}}$ & $0.086^{\mathrm{b}}$ & $0.186^{\mathrm{b}}$ & $0.189^{\mathrm{b}}$ & 0.036 & 0.231 \\
Isoleucine & $0.497^{\mathrm{a}}$ & $0.197^{\mathrm{b}}$ & $0.366^{\mathrm{ab}}$ & $0.419^{\mathrm{a}}$ & 0.107 & 0.458 \\
Leucine & 0.637 & 0.408 & 0.545 & 0.580 & 0.148 & 0.916 \\
Lysine & $0.519^{\mathrm{a}}$ & $0.182^{\mathrm{b}}$ & $0.375^{\mathrm{a}}$ & $0.432^{\mathrm{a}}$ & 0.081 & 0.862 \\
Methionine & $0.162^{\mathrm{a}}$ & $0.037^{\mathrm{b}}$ & $0.047^{\mathrm{b}}$ & $0.081^{\mathrm{ab}}$ & 0.016 & 0.256 \\
Phenylalanine & 0.519 & 0.306 & 0.374 & 0.418 & 0.121 & 0.4103 \\
Threonine & 0.346 & 0.178 & 0.286 & 0.286 & 0.065 & 0.383 \\
Valine & $0.658^{\mathrm{a}}$ & $0.262^{\mathrm{b}}$ & $0.406^{\mathrm{ab}}$ & $0.497^{\mathrm{ab}}$ & 0.144 & 0.584 \\
& & & & & & \\
Nonessential Amino Acids & & & & & \\
Alanine & 0.473 & 0.399 & 0.356 & 0.392 & 0.116 & 0.234 \\
Aspartic acid & $1.121^{\mathrm{a}}$ & $0.412^{\mathrm{b}}$ & $0.842^{\mathrm{a}}$ & $0.866^{\mathrm{a}}$ & 0.216 & 0.863 \\
Cystine & $0.065^{\mathrm{a}}$ & $0.011^{\mathrm{b}}$ & $0.047^{\mathrm{b}}$ & $0.026^{\mathrm{b}}$ & 0.001 & 0.00 \\
Glutamic acid & $1.673^{\mathrm{a}}$ & $0.805^{\mathrm{b}}$ & $1.682^{\mathrm{a}}$ & $1.823^{\mathrm{a}}$ & 0.465 & 1.833 \\
Glycine & $0.605^{\mathrm{a}}$ & $0.186^{\mathrm{b}}$ & $0.416^{\mathrm{a}}$ & $0.573^{\mathrm{a}}$ & 0.120 & 0.225 \\
Proline & 0.496 & 0.330 & 0.438 & 0.472 & 0.117 & 0.863 \\
Serine & 0.330 & 0.214 & 0.375 & 0.313 & 0.103 & 0.484 \\
Tyrosine & $0.346^{\mathrm{a}}$ & $0.157^{\mathrm{b}}$ & $0.165^{\mathrm{b}}$ & $0.249^{\mathrm{ab}}$ & 0.048 & 0.450 \\
Total & 10.10 & 4.39 & 7.60 & 8.33 & & 9.50 \\
\hline
\end{tabular}

'Reference protein $(n=5)$.

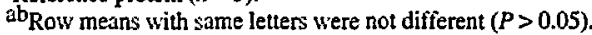

ed species the Japanese quail (NRC 1984). These requirements may be used for making general comparisons for adequacy of seeds meeting bobwhite quail requirements. Based on these comparisons it appears all seeds were deficient in the sulfur-containing amino acids with deficiencies for adult maintenance ranging from 45.9 to $88.6 \%$.

Comparisons of the total nitrogen content (Kjeldahl analysis) to the amino acid nitrogen content (HPLC analysis) reveal that a substantial quantity of nitrogen was contained in nonamino nitrogen constituents (Table 3 ). Mean nonamino nitrogen values ranged from $27.74 \%$ for western ragweed to $47.56 \%$ for common sunflower, but were not different $(P>0.05)$ among plant species. Crude protein concentrations adjusted for nonamino nitrogen yielded estimates of protein content well below crude protein. The calculated average conversion factor for adjusting Kjeldahl nitrogen values to more accurately reflect actual protein concentration was 3.96 , compared with the standard of 6.25 .

\section{Discussion}

The nutritive value of nonamino nitrogen-containing compounds to quail is not entirely clear. Traditionally, nutritionists have used the rule-of-thumb of assigning half the nutritional value of protein nitrogen to nonamino nitrogen (Synge 1963). However, this is inconsistent because it apparently assumes the presence of nutritionally relevant free amino acids such as glycine, alanine, serine, glutamine, and others in the nonamino nitrogen category. We did not include these free amino acids as part of the nonamino nitrogen pool since they were measured (HPLC) as part of the total amino acid pool. The nonamino nitrogen can be used for synthesis of nonessential amino acids when essential amino acid requirements are met and crude protein
Table 3. Measure of total nitrogen (determined by Kjeldhal analysis) and amino nitrogen (HPLC amino acid analysis) in 4 important seed grains in the diet of bobwhites. The percentage of the total nitrogen pool recovered as amino nitrogen was calculated by difference and reported as nonamino nitrogen ( $\%$ NAN). Correction factors for converting total nitrogen determinations (by Kjeldhal analysis) to protein estimates are provided.

\begin{tabular}{lccccc}
\hline \hline Plant & $\begin{array}{c}\text { Kjeldhal } \\
\text { Nitrogen }\end{array}$ & $\begin{array}{c}\text { Amino Acid } \\
\text { Nitrogen }\end{array}$ & NAN & $\begin{array}{c}\text { Correction } \\
\text { Factor }\end{array}$ & $\begin{array}{c}\text { Adjusted } \\
\text { CP }\end{array}$ \\
\hline Croton & (mg N/g DW) & (mg N/g DW) & $(\%)$ & & \\
Paspalum & $26.04 \pm 0.92$ & $14.92 \pm 2.99$ & $42.69 \pm 6.15$ & 3.58 & $9.32 \pm 1.88$ \\
Ragweed & $8.11 \pm 0.46$ & $5.76 \pm 0.45$ & $28.98 \pm 1.89$ & 4.44 & $3.60 \pm 0.28$ \\
Sunflower & $22.12 \pm 1.30$ & $10.60 \pm 0.84$ & $7.74 \pm 4.80$ & 4.52 & $6.63 \pm 0.52$ \\
\end{tabular}

Acrodisc CRPTF, Fisher Scientific, Plano, Tex.

"Waters, Milford, Mass.

'Bovine milk, no. C-0376, Sigma Chem. Co., St. Louis, Mo.

intake is low.

Conversion of Kjeldahl nitrogen to crude protein based on the traditional conversion factor of 6.25 appears to greatly overestimate the amount of true protein present in wild seed grains. The average conversion factor for adjusting Kjeldahl nitrogen determinations to reflect true protein concentration in our study was 3.96.

Digestibility of dietary protein is another important factor that can drastically influence protein requirements and the ability of certain protein sources to meet these requirements (Owens and Pettigrew 1989). Digestibilities of seed from many wild plant species used by bobwhites range from 40 to $90 \%$ (Robel et al. 1979). Both nonamino nitrogen and protein digestibility undoubtedly act in concert to reduce the overall nutritional value of nitrogen and distort the usefulness of crude protein as a measure for determining the adequacy of foods in meeting daily protein requirements.

A solution to the problems associated with assessing protein quality in diets is to compare essential amino acid composition of foods to dietary requirements. Dietary protein and essential amino acid requirements are usually determined experimentally using purified protein sources to formulate rations (with amino acid supplements) with a known essential amino acid composition (Allen and Young 1980, Serafin 1982). Nonamino nitrogen composition in purified protein sources, such as isolated soybean meal protein or casein, would normally be low compared to the whole food source (Bell 1963). Given the large and highly variable concentrations of nonamino nitrogen in wild seed grains compared to purified protein sources and specific dietary requirements for essential amino acids, profiles of concentrations of essential amino acids would provide a more accurate determination of forage quality.

These results highlight important concerns in the use of measures such as crude protein to assess the nutritional quality of common Northern Bobwhite foods, as well as foods of other gallinaceous birds. Because animals have dietary requirements for individual amino acids rather than protein, protein estimates should probably be used as an index of nutritive quality only and not used to assess the ability of particular forages or diets to meet nutrient intake requirements of birds. Failure of previous studies (Roseberry and Klimstra 1984) to find any significant relationships between dietary protein estimates and various intrinsic characteristics of populations (e.g., density, survival rates, 
recruitment rates) could have been due in part to the inherent inaccuracies associated with measures of crude protein.

\section{Literature Cited}

Allen, N. K., and R. J. Young. 1980. Studies on the amino acid protein requirements of laying Japanese quail (Coturnix coturnix japonica). Poult. Sci. 59:2029-2037.

AOAC. 1984. Official Methods of Analysis (14th Ed.). Assoc. of Official Anal. Chem. Washington, D.C.

Baumgartner, F. M., M. J. Morris, J. L. Steel, and J. E. Williams. 1952. Oklahoma bobwhite food relations. Trans. North Amer. Wildl. Nat. Res. Conf. 17:338-358.

Bell, P. M. 1963. A critical study of methods for the determination of nonprotein nitrogen. Anal. Biochem. 5:443- 451.

Bookhout, T. A. 1958. The availability of plant seeds to bobwhite quail in southem Illinois. Ecol. 39:671-681.

Cohen, S. A., M. Meys, and T. L. Tarvin. 1988. The pico-tag method: a manual of advanced techniques for amino acid analysis. Millipore Corporation, Milford, Mass.

Deyoe, C. W., and J. A. Shellenberger. 1965. Amino acids and proteins in sorghum grain. J. Agr. Food Chem. 13:446-450.

Elkin, R. G., and J. E. Griffith. 1985. Hydrolysate preparation for analysis of amino acids in sorghum grains: effect of oxidative pretreatment. $J$. Assac. Official Anal. Chem. 68:1117-1121.

Engle, D. M., J. F. Stritzke, and F. T. McCollum. 1991. Vegetation management in the cross timbers: response of understory vegetation to herbicides and burning. Weed Tech. 5:406-410.

Ewing, A. L., J. F. Strizke, and J. Kulbeth. 1984. Vegetation of the Cross Timbers Experimental Range, Payne County, Oklahoma. Oklahoma Agr. Exp. Sta. Res. Rep. P-856.

Garrison, G. A., A. J. Bjugstad, D. A. Duncan, M. E. Lewis, and D. R. Smith. 1977. Vegetation and environmental features of forest and range ecosystems. UDSA Agr. Handb. 475.

Hang, Y. D., K. H. Steinkraus, and L. R. Hackler. 1980. Amino acid composition of high protein fractions prepared from mung beans, pea beans, and red kidney beans. J. Food Sci. 45:388-389.

Harrold, R. L., and J. D. Nalewaja. 1977. Proximate, mineral and amino acid composition of 15 weed seeds. J. Anim. Sci. 44:389-394.

Holt, N. W., and F. W. Sosulski. 1981. Nonprotein nitrogen contents of some grain legumes. Can. J. Plant Sci. 61:515- 523.

Lochmiller, R. L., J. F. Boggs, S. T. McMurry, D. M. Leslie, Jr., and D. M. Engle. 1991. Response of cottontail rabbit populations to herbicide and fire applications on cross timbers rangeland. J. Range Manage. 44:150-155.

Maynard, L. A., J. K. Loosli, H. F. Hintz, and R. G. Warner. 1979. Animal nutrition. McGraw-Hill Publications, New York, N.Y.

Nestler, R. B., W. W. Bailey, A. C. Martin, and H. E. McClure. 1945. Value of wild feedstuffs for pen-reared bobwhite quail in winter. J. Wildl. Manage. 9:115-120.

Newlon, C. F., T. S. Basket, R. P. Breithenbach, and J. A. Stanford. 1964. Sustaining values of emergency foods for bobwhites. J. Wildl. Manage. 28:532-545.

NRC. 1984. Nutrient Requirements of Poultry (8th Ed.). National Academy Press, Washington, D.C.

Oka, T. O., and K. Sasaoka. 1985. Free amino acids and related compounds in seeds and sprouts of winged bean Psophocarpus tetragonolobus (L.). J. Food Sci. 50:1503-1504.

Owens, F. N., and J. E. Pettigrew. 1989. Subdividing amino acid requirements into portions for maintenance and growth, p. 15- 30. In: M. Friedman (ed.), Absorption and utilization of amino acids. CRC Press.

Robel, R. J., and N. A. Slade. 1965. The availability of sunflower and ragweed seeds during fall and winter. J. Wildl. Manage. 29:202-206.

Robel, R. J., A. R. Bisset, T. M. Clement, Jr., and A. D. Dayton. 1979. Metabolizable energy of important foods of bobwhites in Kansas. J. Wildl. Manage. 43:982-986.

Rollins, D. 1980. Comparative ecology of bobwhite and scaled quail in mesquite grassland habitat. M.S. Thesis. Oklahoma State Univ., Stillwater, Okla.
Roseberry, J. L., and W. D. Klimstra. 1984. Population regulation, p. 151191. In: F. Schwartz (ed.), Population ecology of the bobwhite quail. Southern Illinois Univ. Press, Carbondale and Edwardsville, Ill.

SAS Institute, Inc. 1988. SAS user's guide: statistics. 1988 ed. SAS Institute, Inc., Cary, N.C.

Sedinger, J. S. 1984. Protein and amino acid composition of tundra vegetation in relation to nutritional requirements of geese. J. Wildl. Manage. 48:1128-1136.

Serafin, J. A. 1982. Influence of protein level and supplemental methionine in practical rations for young endangered masked bobwhite quail. Poult. Sci. 61:988-990.

Singh, U., and R. Jambunathan. 1981. Relationship between nonprotein nitrogen and total nitrogen in chickpea (Cicer arietinum L.) seed. J. Agr. Food Chem. 29:423-424.

Spindler, M., R. Stadler, and H. Tanner. 1984. Amino acid analysis of feedstuffs: determination of methionine and cystine after oxidation with preformic acid hydrolysis. J. Agr. Food Chem. 32:1366-1371.

Stritzke, J. F., D. M. Engle, and F. T. McCollum. 1991. Vegetation management in the cross timbers: response of woody species to herbicides and burning. Weed Technol. 5:400-405.

Synge, R. L. M. 1963. Some nutritional aspects of the "non- protein nitrogen" fraction of plants, p. 31-42. In: D. Cuthbertson (ed.), Progress in nutrition and allied sciences. Oliver and Boyd LTD, London, England.

Tobler, S. L., and J. C. Lewis. 1981. Bobwhite foods in six Oklahoma habitats. Proc. Thirty-fourth Ann. Conf. Southeast Assoc. Fish Wildl. Agencies $34: 430-441$.

VanEtten, C. H., W. F. Kwolek, J. E. Peters, and A. S. Barclay. 1967. Plant seeds as protein sources for food or feed. Evaluation based on amino acid composition of 379 species. J. Agr. Food Chem. 15:1077-1089.

Webb, W. M., and F. S. Guthery. 1982. Response of bobwhite to habitat management in northwest Texas. Wildl. Soc. Bull. 10:142-146.

White, T. C. R. 1978. The importance of a relative shortage of food in animal ecology. Oecologia 33:71-86.

Wiseman, D. S. 1977. Food habits and weights of bobwhite from northeastem Oklahoma tall grass prairie. Prac. Okla. Acad. Sci. 57:110-115.

Wiseman, D. S., and J. C. Lewis. 1981. Bobwhite use of habitat in tallgrass rangelands. Wildl. Soc. Bull. 9:248-255.

Wood, K. N., F. S. Guthery, and N. E. Koerth. 1986. Spring- summer nutrition and condition of northem bobwhites in south Texas. J. Wildl. Manage. 50:84-88. 